\title{
Genetic and phenotypic variation of some reproductive traits in Egyptian buffalo
}

\author{
M.A. Aziz ${ }^{1}$, S.J. Schoeman ${ }^{2 \#}$, G.F. Jordaan ${ }^{2}$, O.M. El-Chafie ${ }^{3}$ and A.T. Mahdy ${ }^{1}$ \\ ${ }^{1}$ Department of Animal Production, Faculty of Agriculture, Alexandria University, Alexandria, Egypt; ${ }^{2}$ Department of \\ Animal Science, University of Stellenbosch, South Africa; ${ }^{3}$ Animal Research Institute, Ministry of Agriculture, Cairo, \\ Egypt
}

\begin{abstract}
The objectives of this study were to determine the effects of season, year of calving and parity on lactation period, calving interval, number of days open and dry period in Egyptian buffalo, and to estimate genetic and phenotypic parameters for these traits using a multi-trait animal model. Season of calving, year of calving and parity affected the traits studied. Heritability estimates for lactation period, calving interval, dry period and number of days open were $0.09,0.07,0.13$ and 0.08 respectively and repeatability estimates were $0.27,0.14,0.27$ and 0.19 respectively. Estimates of the permanent environmental component $\left(\mathrm{c}^{2}\right)$ were low. Genetic correlations between these traits were low and positive, except for that between lactation period and dry period, which was negative. A similar pattern was observed for phenotypic correlations, but these were higher than those observed for genetic correlations.
\end{abstract}

Keywords: Buffalo, calving interval, days open, dry period, heritability.

${ }^{\#}$ Author to whom correspondence should be addressed; e-mail: sjsc@ maties.sun.ac.za

\section{Introduction}

Short lactation periods, long calving intervals, long dry periods and a large number of days open are characteristics typical of buffalo cows. These traits have low heritabilities, and means are associated with a large degree of variation due to numerous environmental factors (Mourad, et al., 1989; Parakash, et al., 1989; Khalil, et al., 1991; Afifi, et al., 1992; Ibrahim, 1998; Khan \& Akhtar, 1998; Penchev, 1998; Suhail, et al., 1998; Tiwana \& Dhillon, 1998; Vasconcellos \& Tonhati, 1998; Tonhati et al., 2000). A sound knowledge of the source of this variation is essential for the application of sound breeding and management practices. The objectives of this study were to determine the effects of some environmental factors on lactation period, calving interval, dry period and number of days open, and to estimate heritabilities, repeatabilities and genetic and phenotypic correlation coefficients between the above-mentioned traits.

\section{Materials and Methods}

Data for this study were obtained from a herd belonging to the Animal Production Research Institute of the Egyptian Ministry of Agriculture located in Mehallet Mousa, Kafr El-Sheikh Governorate. A total of 2505 records were collected between 1979 and 1992. Animals were fed Egyptian clover ad libitum from October to May and were supplemented with a concentrate mixture according to milk production. From June to September, animals were given a concentrate mixture with wheat or rice straw and a limited amount of hay when available. Heifers were bred for the first time at 24 months of age and the average age of cows was 6.3 years. Cows were usually served two months after calving by natural mating to sires that were chosen at random.

The data set was edited to exclude missing values. Records with missing parent identification data were included in the analysis. The editing procedure reduced the size of the data set to 1589 records, representing the performance of 544 cows and 87 sires. Data were classified according to cow, sire, dam, year of calving, season of calving and parity. Year was divided into two seasons, viz. winter (October to March) and summer (April to September). The traits studied were lactation period, calving interval (d), dry period (d), and number of days open. The number of days open was calculated as the difference between the interval between two consecutive calvings and a constant gestation period (318 days). Parities numbering eight or more were classified together. 
Data were analysed by least squares analysis with unequal subclass numbers using the PROC GLM procedure of SAS (1990). The model used was :

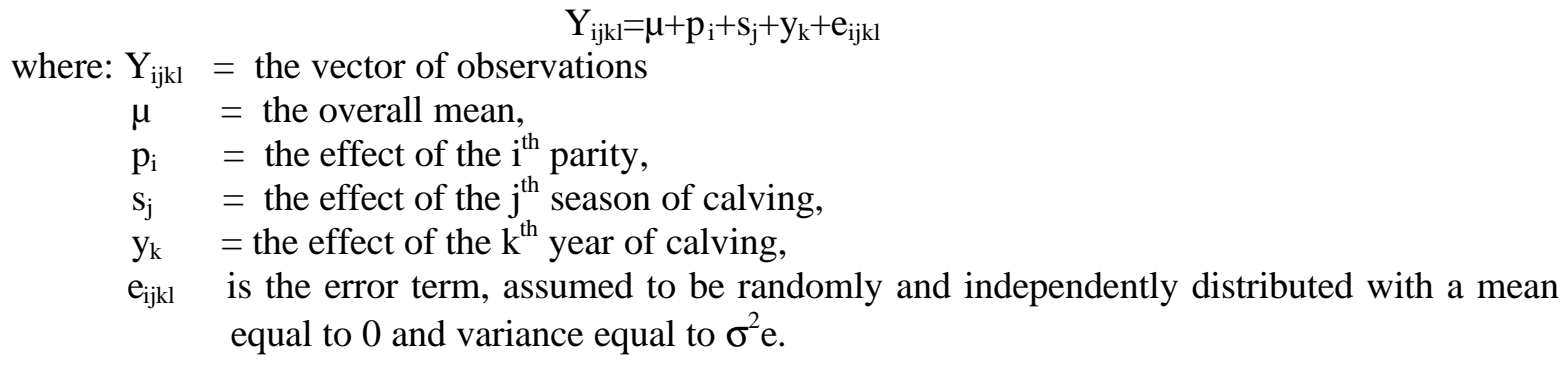

All factors in the model except the error term were assumed to be fixed. Differences between means were evaluated using the Duncan Multiple Range Test (Steel \& Torrie, 1980). Subsequently, a multitrait repeatability animal model was fitted using the VCE 4.2.5 package of Groeneveld (1994, 1997) and Groeneveld \& Garcia Cortés (1998). The model previously assumed was fitted to the same data with the inclusion of additive genetic and permanent environment as additional random effects. Repeatability estimates were obtained from the equation:

$$
t=\left(\sigma_{a}^{2}+\sigma_{c}^{2}\right) / \sigma_{p}^{2}
$$

where $\begin{array}{lll}\sigma_{\mathrm{a}}^{2} & = & \text { additive genetic variance } \\ \sigma_{\mathrm{c}}^{2} & = & \text { permanent environmental variance } \\ \sigma_{\mathrm{p}}^{2} & = & \text { total phenotypic variance }\end{array}$

No asymptotic standard errors were computed for the genetic parameters.

\section{Results and Discussion}

Mean squares for factors affecting lactation period, calving interval, dry period and number of days open are presented in Table 1. Parity, season of calving and year of calving had an effect $(\mathrm{P} \leq 0.01)$ on the traits studied.

Table 1 Mean squares of factors affecting lactation period, calving interval, dry period and number of days open in Egyptian buffalo

\begin{tabular}{cccccc}
\hline \multirow{2}{*}{ Source of variation } & \multirow{2}{*}{ df } & \multicolumn{4}{c}{ Mean Square } \\
\cline { 3 - 6 } & & Lactation period & Calving Interval & Dry Period & $\begin{array}{c}\text { Number of Days } \\
\text { open }\end{array}$ \\
\hline Parity & 7 & $390513.86^{* *}$ & $173217.10^{* * *}$ & $947830.00^{* * *}$ & $173217.10^{* * *}$ \\
Season of calving & 1 & 8218.24 & $240785.69^{* * *}$ & $151093.43^{* *}$ & $240785.69^{* * *}$ \\
Year of calving & 13 & $75905.91^{* *}$ & $75876.77^{* * *}$ & $51246.65^{* *}$ & $75876.77^{* *}$ \\
Error & 1567 & 11682.58 & 12312.38 & 17152.11 & 12312.38 \\
$\mathrm{R}^{2}(\%)$ & & 15 & 16 & 26 & 16 \\
\hline
\end{tabular}

$* * \mathrm{P}<0.01$

Regression equations of the four traits on parity number are presented in Table 2, while least squares means for the four traits classified by season of calving and year of calving are shown in Table 3 . Lactation period was the shortest for the first parity and did not differ $(\mathrm{P}>0.05)$ between the other parities.

Table 2 Regressions of least squares means for lactation period, calving interval, dry period and number of days open $(\mathrm{Y})$ on parity number $(\mathrm{X})$

\begin{tabular}{lcccc}
\hline Trait & Mean $(\mathrm{d})$ & $\mathrm{CV}(\%)$ & Regression & $\mathrm{R}^{2}$ \\
\hline Lactation period & 208.6 & 51.7 & $\mathrm{Y}=128.9+37.9 \mathrm{X}-3.34 \mathrm{X}^{2}$ & 0.71 \\
Calving interval & 518.9 & 27.0 & $\mathrm{Y}=599.6-40.6 \mathrm{X}+2.92 \mathrm{X}^{2}$ & 0.94 \\
Dry period & 307.3 & 51.3 & $\mathrm{Y}=469.9-78.2 \mathrm{X}+6.22 \mathrm{X}^{2}$ & 0.92 \\
Number of days open & 199.5 & 68.1 & $\mathrm{Y}=218.6-40.6 \mathrm{X}+2.92 \mathrm{X}^{2}$ & 0.94 \\
\hline
\end{tabular}


All traits were characterized by large coefficients of variation. The highest least squares mean for calving interval was recorded between the first and second parities and the lowest for the fifth parity. This differed $(\mathrm{P} \leq 0.05)$ from the means of other parities.

Season of calving did not have any effect on lactation period $(\mathrm{P}>0.05)$, but cows that calved in winter had longer calving intervals, longer dry periods and a greater number of days open than those that calved in summer $(\mathrm{P}<0.01)$. No trend was evident for least squares means over years of calving for any of the traits studied. However, means for lactation period decreased from a maximum in 1979 to a minimum in 1984, after which they fluctuated between years. The longest calving interval and the greatest number of days open occurred in 1980. The shortest calving interval and the lowest number of days open occurred in 1992. The longest dry period was in 1985 and the shortest dry period was in 1979. The results of this study are in agreement with the findings of Mourad et al. (1989), Shah (1990), Khalil et al. (1991), Ibrahim (1998) and Vasconcellos \& Tonhati (1998) for different breeds of water buffalo. These workers reported that year of calving and parity had significant effects on lactation period, calving interval, dry period and number of days open. However, Afifi et al. (1992) reported that year of calving had no effect on calving interval in the Egyptian buffalo, although it affected the number of days open. In contrast Parakash et al. (1989) observed no effect of year of calving on calving interval, dry period and number of days open for Murrah buffalo. The results of this study are in agreement with those of Mourad et al. (1989), Parakash et al. (1989), Khalil et al. (1991), Afifi et al. (1992) and Ibrahim (1998) who found that calving interval decreased with parity. Their results also indicated that least squares means of year of calving fluctuated considerably over years. Vasconcellos \& Tonhati (1998) did not detect any distinct pattern for lactation period with year of calving or age in Murrah buffalo and attributed their results to the effect of herd management. On the other hand, they found that means for calving interval were homogenous across years studied.

Table 3 Least square means ( \pm s.e.) for the effects of season of calving and year of calving on lactation period, calving interval, dry period and number of days open

\begin{tabular}{|c|c|c|c|c|}
\hline & Lactation period & Calving interval & Dry period & $\begin{array}{l}\text { Number of } \\
\text { Days open }\end{array}$ \\
\hline \multicolumn{5}{|c|}{ Season of calving } \\
\hline Winter & $228.72 \pm 5.23^{\mathrm{a}}$ & $508.73 \pm 5.37^{\mathrm{a}}$ & $279.66 \pm 6.34^{\mathrm{a}}$ & $190.73 \pm 5.37^{\mathrm{a}}$ \\
\hline Summer & $224.08 \pm 4.98^{\mathrm{a}}$ & $483.59 \pm 5.11^{\mathrm{b}}$ & $259.75 \pm 6.03^{\mathrm{b}}$ & $165.59 \pm 5.11^{\mathrm{b}}$ \\
\hline \multicolumn{5}{|c|}{ Year of calving } \\
\hline 1979 & $314.42 \pm 25.62^{\mathrm{a}}$ & $512.23 \pm 28.30^{\mathrm{b}}$ & $198.40 \pm 31.04^{\mathrm{bc}}$ & $194.24 \pm 26.30^{b}$ \\
\hline 1980 & $299.14 \pm 13.72^{\mathrm{abc}}$ & $584.11 \pm 14.08^{\mathrm{a}}$ & $285.40 \pm 16.62^{\mathrm{a}}$ & $266.11 \pm 14.08^{\mathrm{a}}$ \\
\hline 1981 & $255.10 \pm 14.09^{\mathrm{abc}}$ & $494.57 \pm 14.46^{\mathrm{bc}}$ & $239.68 \pm 17.07^{\mathrm{bcd}}$ & $176.57 \pm 14.46^{\mathrm{bc}}$ \\
\hline 1982 & $227.33 \pm 11.22^{\mathrm{abcd}}$ & $486.03 \pm 11.52^{\mathrm{cd}}$ & $258.87 \pm 13.60^{\mathrm{bc}}$ & $168.03 \pm 11.51^{\mathrm{cd}}$ \\
\hline 1983 & $204.62 \pm 9.08^{\mathrm{d}}$ & $483.88 \pm 9.32^{\text {cde }}$ & $277.40 \pm 11.00^{\mathrm{b}}$ & $165.88 \pm 9.32^{\text {cde }}$ \\
\hline 1984 & $190.11 \pm 8.98^{\mathrm{cd}}$ & $502.61 \pm 9.22^{\mathrm{cd}}$ & $312.44 \pm 10.69^{b}$ & $184.61 \pm 9.22^{\mathrm{cd}}$ \\
\hline 1985 & $192.63 \pm 11.57^{\mathrm{abcd}}$ & $488.23 \pm 11.89^{\text {cde }}$ & $295.58 \pm 14.03^{\text {bcde }}$ & $170.23 \pm 11.69^{\text {cde }}$ \\
\hline 1986 & $218.72 \pm 11.37^{\mathrm{ab}}$ & $510.56 \pm 11.67^{\mathrm{cd}}$ & $291.82 \pm 13.77^{\text {cdef }}$ & $192.65 \pm 11.67^{\mathrm{cd}}$ \\
\hline 1987 & $193.94 \pm 10.94^{\mathrm{abcd}}$ & $461.11 \pm 11.23^{\mathrm{fg}}$ & $267.16 \pm 13.25^{\mathrm{ef}}$ & $143.11 \pm 11.23^{\mathrm{fg}}$ \\
\hline 1988 & $216.28 \pm 9.84^{\mathrm{abc}}$ & $480.72 \pm 10.10^{\text {ef }}$ & $284.45 \pm 11.92^{\mathrm{f}}$ & $162.72 \pm 10.10^{\mathrm{def}}$ \\
\hline 1989 & $205.50 \pm 9.22^{\mathrm{abcd}}$ & $497.39 \pm 9.46^{\mathrm{def}}$ & $291.81 \pm 11.17^{\mathrm{def}}$ & $179.39 \pm 9.46^{\text {def }}$ \\
\hline 1990 & $222.57 \pm 8.97^{\mathrm{ab}}$ & $508.20 \pm 9.21^{\mathrm{def}}$ & $285.64 \pm 10.87^{\mathrm{ef}}$ & $190.20 \pm 9.21^{\mathrm{def}}$ \\
\hline 1991 & $224.35 \pm 8.59^{\mathrm{ab}}$ & $495.51 \pm 8.82^{\mathrm{def}}$ & $271.14 \pm 10.41^{\mathrm{f}}$ & $177.51 \pm 8.82^{\mathrm{def}}$ \\
\hline 1992 & $204.89 \pm 14.30^{\mathrm{bcd}}$ & $440.92 \pm 14.68^{\mathrm{g}}$ & $236.04 \pm 17.33^{\mathrm{f}}$ & $122.92 \pm 14.68^{\mathrm{g}}$ \\
\hline
\end{tabular}

${ }^{\mathrm{a}-\mathrm{g}}$ Column means without common superscripts differ $(\mathrm{P}<0.05)$

Heritabilities, repeatabilities, genetic correlations and phenotypic correlations are presented in Table 4. Heritability estimates were low, and the highest heritability was 0.13 which was recorded for dry period. The only noteworthy repeatability estimates were those for lactation period and dry period $(0.27)$. Genetic correlations between traits were positive, with the exception of that between lactation period and dry period. Phenotypic correlations were of medium magnitude and were greater than genetic correlations. All coefficients were positive, except that between lactation period and dry period. The highest correlation was between calving interval and number of days open (0.90). 
The heritability estimates obtained in this study are in agreement with those reported by Mourad et al. (1989), Parakash et al. (1989), Khalil et al. (1991), Afifi et al. (1992), Penchev (1998), Tiwana \& Dhillon (1998) and Tonhati et al. (2000) for different breeds of buffaloes. They also reported low heritability estimates for lactation period, calving interval, dry period and number of days open. Genetic correlation estimates reported by these authors are also in agreement with those obtained in this study. However, they reported positive genetic correlations between lactation period and dry period.

Table 4 Heritabilities (bold) and repeatabilities (on the diagonal), genetic correlations (above the diagonal) and phenotypic correlations (below the diagonal), for lactation period, calving interval, dry period and number of days open in the Egyptian buffalo

\begin{tabular}{lcccc}
\hline Trait & Lactation period & Calving interval & Dry period & Number of days open \\
\hline Lactation period & $\mathbf{0 . 0 9}$ & 0.09 & -0.29 & 0.07 \\
& 0.27 & & & \\
Calving interval & 0.47 & $\mathbf{0 . 0 7}$ & 0.22 & 0.30 \\
& & 0.14 & & 0.21 \\
Dry period & -0.37 & 0.49 & $\mathbf{0 . 1 3}$ & \\
& & & 0.27 & $\mathbf{0 . 0 8}$ \\
$\begin{array}{l}\text { Number of days } \\
\text { open }\end{array}$ & 0.47 & 0.90 & 0.47 & 0.19 \\
\hline
\end{tabular}

\section{Conclusions}

Poor reproductive efficiency was observed in the herd investigated in this study. The results indicated that the animals had short lactation periods, long calving intervals, long dry periods and a large number of days open. The very low heritability estimates coincided with low genetic correlations between traits and moderate phenotypic correlations. The permanent environmental component and repeatabilities were also relatively low. It was concluded that the traits studied were mostly influenced by non-genetic factors. There should be scope for reducing the length of the calving interval and days open in the current herd by means of selection, efficient management regimes and proper feeding.

\section{Acknowledgement}

\section{References}

Study leave of M.A. Aziz was supported by a grant from UNESCO.

Afifi, E.A., Khalil, M.H., Bedeir, L.H. \& Zeidan, S.M., 1992. Genetic analysis of reproductive traits in Egyptian buffaloes. Egypt. J. Anim. Prod., 29, 139-154.

Groeneveld, E., 1994. VCE- a multivariate, multimodel REML covariance component estimation package. Proc. $5^{\text {th }}$ World Congress Genet. Appl. Livest. Prod., 22, 47-50 (Guelph, Canada).

Groeneveld, E., 1997. VCE-4, User's guide and reference manual. Institute of Animal Husbandry and Animal Behaviour, Mariensee, Germany.

Groeneveld, E. \& Garcia Cortés, A., 1998. VCE 4.0, a (co)variance component package for frequentists and Bayesians. Proc $6^{\text {th }}$ World Congress Genet. Appl. Livest. Prod., 27, 455-458 (Armidale, Australia).

Ibrahim, S.A., 1998. Analysis of non-genetic factors affecting calving interval and post-partum traits in Egyptian buffaloes. Egypt. J. Anim. Prod. 35, 597-607.

Khalil, M.H., Mourad, K.A., Mohamed, M.M. \& Owen, J.B., 1991. Genetic and phenotypic evaluation for reproductive performance of Egyptian buffaloes. Anim. Prod. 52, 75-82.

Khan, R.N. \& Akhtar, S., 1998. Production characteristics of Nili-Ravi buffaloes. Asian-Australian J. Anim. Sci. 12, 56-60.

Mourad, Kawthar A., Khattab, A.S. \& Ibrahim, M.A.R., 1989. Effect of genetic and non-genetic factors on reproductive traits in Egyptian buffaloes. Buffalo Bulletin 8, 9-16. 
Parakash, A., Tripathi, V.N. \& Tomer, S.S., 1989. Genetic analysis of reproductive traits of Murrah buffaloes. Indian J. Dairy Sci. 42, 426-430.

Penchev, P, 1998. Phenotypic and genotypic evaluation of the buffalo population bred in Bulgaria. Bulgarian J. Agric. Sci. 4, 463-469.

SAS, 1990. SAS User's Guide: Statistics. 1990 edition, Cary, NC, USA.

Shah, N.H., 1990. Prolonged calving intervals in the Nili-Ravi buffalo. Ph.D. dissertation, Faculty of Diergeneeskunde, Utrecht, the Netherlands.

Steel, R.G.D. \& Torrie, J.H., 1980. Principles and Procedures of Statistics. Second edition, McGraw-Hill Book Co., New York.

Suhail, S.M., Syed, M. \& Amjad, M., 1998. Production and reproduction performance of Nili-Ravi buffaloes in N.W.F.P. Peshawar. Sarhad J. Agric. 14, 403-406.

Tiwana, M.S. \& Dhillon, J.S., 1998. Genetic improvement of buffalo productivity under farm and field conditions. In Souveu. Seminar on problems of buffalo reproduction and their solutions. [edited by R.K. Sethi and S.K. Jindal]. October, 16, 1998. Hisar, India.

Tonhati, H., Vasconcellos, F.B. \& Albuquerque, L.G., 2000. Genetic aspects of productive and reproductive traits in a Murrah buffalo herd in São Paulo, Brazil. J. Anim. Breed. Genet. 117, 331-336.

Vasconcellos, B.F. \& Tonhati, H., 1998. Inbreeding and its effects on some productive and reproductive traits in a Murrah buffalo herd. J. Anim. Breed. Genet. 115, 299-306. 